Nadwa : Jurnal Pendidikan Islam

Vol. 14, No.1 (2020)

Accredited by Ristekdikti based on Decree No. 51/E/KPT/2017

DOI: $10.21580 /$ nw.2020.14.1.5881

\title{
Islamic Education and Da'wah Strategies Based on Culture in the Ilir-ilir Song of Sunan Kalijaga
}

\author{
Mulyono \\ UIN Maulana Malik Ibrahim Malang \\ E-mail: mulyonouin@gmail.com
}

\section{Abstract}

The purpose of this study is to examine the educational and $d a$ 'wah strategies based on the culture in the Song Ilir-ilir Sunan Kalijaga. By using library research methods and content analysis techniques, the results as follows: 1) With a cultural approach, Sunan Kalijaga invites and educates the public to embrace Islam as a new religion that came to Java around the 13-15 century AD. 2). Persuasively, Sunan Kalijaga made people aware of Islam by carrying out the five pillars of Islam while leaving all beliefs and deeds prohibited by Islam. 3) With the metaphor of Blimbing (star fruit). Sunan Kalijaga assures people that whoever obeys the commands of Islam, will find peace and happiness in living in this world and the hereafter. Educators and preachers in various events create the Ilir-ilir Song as a cultural-based educational and da'wah strategy that remains popular in the millennial era.

Keywords: Islamic education, da'wah, Lir-Ilir; cultural;

\section{Abstrak}

Tujuan penelitian ini untuk mengkaji strategi pendidikan dan dakwah Islam berbasis kultural dalam lagu Ilir-ilir Sunan Kalijaga. Dengan menggunakan metode penelitian kepustakaan (library research) dan teknik analisis isi (content analisys), maka hasilnya dapat disimpulkan berikut: 1) Dengan pendekatan kultural, Sunan Kalijaga mengajak dan mendidik masyarakat untuk memeluk Islam sebagai agama baru yang datang ke tanah Jawa sekitar abad 13-15 M. 2) Secara persuasif, Sunan Kalijaga menyadarkan masyarakat untuk memeluk Islam dengan melaksanakan rukun Islam yang lima seraya meninggalkan segala keyakinan dan perbuatan yang dilarang Islam; 3) Dengan metafora buah blimbing, Sunan Kalijaga menyakinkan masyarakat bahwa barangsiapa yang taat menjalankan perintah Islam, kelak mendapatkan ketentraman dan kebahagiaan hidup di dunia dan di akhirat. Para pendidik maupun juru dakwah dalam berbagai event mengkreasi lagu Ilir-ilir sebagai strategi pendidikan dan dakwah berbasis kultural yang tetap populer di era millineal.

Kata Kunci: Pendidikan Islam; Da'wah; kultural; walisongo; sunan kalijaga;

ISSN 1979-1739 (P) ; ISSN 2502-8057 (E).

(C) 2020 Nadwa : Jurnal Pendidikan Islam | UIN Walisongo.

Accredited by Ristekdikti based on Decree No. 51/E/KPT/2017

http://journal.walisongo.ac.id/index.php/nadwa 


\section{Introduction}

Islamic education and da'wah strategy amid a pluralistic society, not only requires knowledge and understanding of Islamic teachings correctly and completely (kaffah), but also knowledge and understanding of social ethics and good ways of society, by always considering socio-cultural reality where the teachings of Islam are about to be grounded. Efforts to implement the Amar ma'ruf nahi munkar as a primary Islamic education and da'wah mission must be based on love. Education and preaching based on hatred often make efforts to spread Islamic values fail, because of unfriendly attitudes, as the word of God in the Qur'an, Surah An-Nahl:

"Cried (man) to the path of your Lord with good wisdom and lessons and refute them in a good manner. Indeed, your Lord is $\mathrm{He}$ who knows better who is lost from His ways and $\mathrm{He}$ who knows better those who are guided. (Surah An-Nahl [16], 125)".

The verse hints at the importance of an educational and propaganda strategy that enlightens and soothes, not precisely by building up fears especially hatred towards other people/groups. Islamic education and da'wah strategies during a plural society must not offend or even hurt the community, on the contrary, the educational and $d a$ 'wah approach must always maintain people's feelings, this is where persuasion education and communication strategies are needed.

Lately, there has been a phenomenon of Islamic education and $d a$ 'wah that tries to distance religion from the traditions and culture of the community that have existed for decades and even for centuries. Yet in reality, the Prophet Muhammad often makes the culture ('urf) of Arab society as a normative basis in conveying the message of Islam, both religious and mu'amalah dimensions. One example is the tradition of the tawaf (circling 
the Kaaba) with no clothes practiced by the Arab community before Islam. even though it (the bare condition) is contrary to the teachings of Islam, but the culture of tawaf was not eliminated, but improved by providing an alternative that is by using Ihram clothing (clothing that is holy, white and without sewing/shape). Even thawed later became one of the pillars of the Pilgrimage agreed by jumhur ulama'. This shows that the inevitability of a tradition and culture in society can be a new shariah in Islam. The statement contains wisdom that Islam turns out to be perfect teaching, closely related to the cultural processes that take place in society. That is why the spread of Islam in Indonesia, which was once called the Archipelago (Nusantara), especially Java, which was pioneered by Wali Songo with an educational strategy and cultural propaganda, proved to be a resounding success. 1

Wali Songo in Java, the ulama's in Minangkabau Padang Panjang, and the Datuk who spread Islam in South Sulawesi, as well as the ulama before and after, they preferred to use education and $d a$ 'wah strategies with traditional and cultural approaches. The cultural preaching education strategy emphasizes dialogue and the process of socialization that takes place gradually. This model of preaching education strategy requires extra patience because it emphasizes harmonizing community relations and avoiding social friction and conflict.

Educational and $d a$ 'wah strategies with cultural approaches have proven to be more effective and lasting; the deepest messages of religion can be conveyed elegantly to the public. This is certainly different from the education and propaganda strategy by using certain authorities, such as political, economic, mass media, and so on. Related to this rationale, in this discussion the author focus on the study of: "What are the educational and

1 Abdurrohman Kasdi, "The Role of Walisongo in Developing the Islam Nusantara Civilization," Addin 11, no. 1 (2017): 1-26. 
da'wah strategies based on cultural in the Ilir-ilir song of Sunan Kalijaga that remain popular in the millennial era?"

Research method of this study is library research. With library research, this study uses descriptive analytic methods, that is: data obtained in the form of words, pictures and behaviors that are not stated in numbers or statistics, but remain in qualitative form by describing the situation understudy in the form of narrative descriptions. 2 To sharpen the analysis of qualitative descriptive methods, the researcher uses content analysis techniques (content analysis), which is an analysis that emphasizes scientific analysis of the message content of communication. 3 The content analysis utilizes procedures that can draw authentic conclusions from a book or document. 4 The content analysis process is started from the contents of the communication messages, sorted and selected (sorted), then categorized (grouping) between similar data, and then analyzed critically and objectively.5

\section{Understanding Cultural Terms}

Cultural or everyday language with the term "culture" comes from Sanskrit, namely buddhayah. It is a plural form of buddhi (mind or reason), interpreted as matters relating to the human mind and reason. In English, tradition is called culture. Derived from the Latin word colere, which is processing or

2 S Margono, "Metode Penelitian Pendidikan, PT," Rineka Cipta, Jakarta, 2000. Hal 39

3 Moelong, "Lexy. 2012," Metode Penelitian Kualitatif. Bandung: PT Remaja Rosdakarya, n.d. hal. 163-64

4 Noeng Muhadjir, "Metode Penelitian Kualitatif Edisi IV," Yogyakarta: Rake Sarasin, 2000. Hal.

5 Bleicher Joseph, "Contemporary Hermeneutics" (London: Routledge and Kegan Paul, 1980). Hal. 28 
working. It could also be interpreted as cultivating land or farming. The word culture is also sometimes translated as "culture" in Indonesian.6

In Islam, the term culture or culture is called $a d a b$. Islam outlines the Islamic customs that govern the ethics and norms of its adherents. These Islamic customs include all aspects of human life. His guidance came directly from Allah through revelation to His Messenger. Therefore, Allah Most High. make His Messenger. as the best example in terms of ethics and manners.

\section{Education Strategy Based on Cultural}

According Rusydi, a culture-based education strategy is an education that is held to meet national standards of education enriched with comparative and competitive advantages based on noble cultural values so that students and the wider community can actively develop their potential to become superior human beings, intelligent, visionary, sensitive to the environment and cultural diversity, and responsive to world developments. These cultural noble values include 18 types of values, including honesty, humility, order/discipline, decency, courtesy/politeness, patience, cooperation, tolerance, responsibility, justice, caring, self-confidence, self-control, integrity, work hard/tenacity/ perseverance, accuracy, leadership, and/or toughness.7

The cultural noble value in question is identical to character education which must be instilled in students through various strategies. According to Rusydi, instilling cultural noble values in students is not an easy thing, but can be pursued with

6 Syamsul Anwar, "Pandangan Islam Terhadap Kesenian," Yogyakarta: Majelis Kebudayaan Muhammadiyah. Universitas Ahmad Dahlan, 1995.

7 Ibnu Rusydi, "Pendidikan Berbasis Budaya Cirebon," Intizar 20, no. 2 (2014): 327-48. 
exemplary strategies, programs and concrete actions, and habituation of these 18 values. 8

\section{Da'wah Strategy Based on Cultural}

Nuh in his book, "Stategi Dakwah dan Pendidikan Umat" provides several forms of da'wah strategies for the transformation of the people including 1) Paying attention to priorities; 2) start the da'wah by aligning understanding and deepening people's awareness of reality; 3) delivering da'wah through comprehensive, synergistic and balanced understanding and practice; 4) making God's pleasure the goal; 5) understand and use social law; 6) patient, determined, and calm.9

Munir explains that cultural propaganda, in general, can be understood as developing propaganda through cultural channels, through informal channels, for example through community development, cultural, social, and other informal forms. 10 Muhammad Sulthon also explained that cultural propaganda is a propaganda activity that emphasizes cultural Islam. Cultural Islam is one approach that seeks to revisit the formal doctrinal links between Islam and politics or Islam and the state. Or in other words, preaching outside of power.11

$D a$ 'wah strategy based on cultural is a da'wah approach by paying attention to the tendency of $\operatorname{mad}^{\prime} \hat{u}$ (listeners, the public)

8 Rusydi. 327-348

9 Sayyid Muhammad Nuh, Stategi Dakwah Dan Pendidikan Umat (Yogyakarta: Himam Prisma Media, 2004). Hal 54

10 Samsul Munir Amin and Baihaqi Nu'man, Rekonstruksi Pemikiran Dakwah Islam (Amzah, 2008). Hal. 179

11 Muhammad Sulthon, H M Amin Syukur, and M Adib Abdushomad, Menjawab Tantangan Zaman: Desain Ilmu Dakwah: Kajian Ontologis, Epistemologis Dan Aksiologis (Pustaka Pelajar diterbitkan atas kerjasama dengan Walisongo Press, 2003). Hal. 26 
as a cultural being. Da'wah that pays attention to the tendency of mad' $\hat{u}$ (listeners) as the target will make it very easy for the delivery of Islamic $d a$ 'wah messages.

\section{Forms and Cultural Values Developed}

According to Rusydi, the cultural form can be in the form of abstract idioms (customs, behavior) located in the minds of the people. The second form is a social system of behavior patterned from humans themselves. Concrete in nature can be observed. The third form is the most concrete physical culture and objects that can be touched and seen. The three forms of culture above in the reality of community life are not separate from one another. 12

The forms of regional culture can be in the form of (a) regional stories with values contained in regional stories such as the value of obedience and respect for parents in the Malin Kundang story, the value of women's emancipation in the Roro Mendut story, the value of the wife's loyalty in the story of Banyuwangi, (b) Dances with values contained in dance arts such as Heroes, agility, agility, and spirit and spiritual values, (c) Songs or regional songs that contain religious values such as Ilir-Ilir, (d) Games containing flexibility, accuracy, agility, and togetherness, (e) performing arts that contain the values of guidance and divinity, heroism, and beauty, and (f) local customs or traditions that contain values of harmony and balance.

\section{Research Result}

\section{a Brief History of Sunan Kalijaga}

Sunan Kalijaga or Sunan Kalijogo is one of the members of Wali Songo who is very well known among the santri and abangan communities on the island of Java, because of his ability to incorporate Islamic influence into Javanese tradition. Sunan

12 Rusydi, "Pendidikan Berbasis Budaya Cirebon." 
Kalijaga was born in 1455 AD. In various histories, it is explained that at a young age, Sunan Kalijaga was named Raden Said or Jaka Said, also known as Shaykh Malaya, Lokajaya, Raden Abdurrahman and Pangeran Tuban (IAIN Walisongo, 1982). He is the son of the Duke of Tuban named Tumenggung Wilatikta or Raden Sahun. Duke of Tuban descended from Majapahit rebel leader Ronggolawe. Based on one version of the Cirebon community, the name Kalijaga comes from the Kalijaga Village in Cirebon. When Sunan Kalijaga stayed there, he often soaked in the river (Kali), or guarded the river.

The life span of Sunan Kalijaga is estimated to reach more than 100 years. Thus he experienced the end of Majapahit rule (ending 1478), the Sultanate of Demak, the Sultanate of Cirebon and Banten, even the Kingdom of Pajang, born in 1546 and the beginning of the presence of the Kingdom of Mataram under the leadership of Panembahan Senopati. He also designed the construction of the Cirebon Great Mosque and the Great Mosque of Demak. The "tatal" pole (wood shards) which is one of the main pillars of the mosque is the creation of Sunan Kalijaga.

In one history, Sunan Kalijaga is said to be married to Dewi Saroh bint Maulana Ishak, by having 3 sons: R. Umar Said (Sunan Muria), Dewi Rakayuh and Dewi Sofiah. Maulana Ishak has a child named Sunan Giri and Dewi Saroh. They are brothers. In preaching, Sunan Kalijaga has the same pattern as a mentor as well as his best friend, Sunan Bonang. His religious ideology tends to be "salaf-based Sufism" - not pantheistic Sufi (mere worship). He uses art and culture as a means and approach to preaching.

Sunan Kalijaga is very tolerant of local culture. He argues that people would stay away if got attack against their principles. Then the community must be approached gradually in stages, the principle follows while influencing. That is one method of 
preaching Sunan Kalijaga. Sunan Kalijaga believes that if Islam is understood, the old habits will naturally disappear. He always flexibly introduced religion without eliminating the customs/arts of the region (old customs which he gave an Islamic color) that had existed before. He is famous for his $d a$ 'wah whose teachings seem syncretistic in introducing Islam. He uses carving, wayang, gamelan, and suluk sound art. One of the well-known voice artworks by Sunan Kalijaga is Ilir-ilir song. 13 The da'wah approach is very effective. Most of the dukes on Java embraced Islam through Sunan Kalijaga; among them is Duke of Pandanaran, Kartasura, Kebumen, Banyumas, and Pajang.When he died, he was buried in Kadilangu Village, near the town of Demak Bintara. This tomb has been visited by people from all over Indonesia.

\section{Ilir-ilir Song}

Ilir-ilir is one of the Javanese songs created by Sunan Kalijaga to carry out Islamic education and $d a$ 'wah in Javanese society. Sunan Kalijaga is very familiar to the people especially in Java, he is very famous for his various works as a medium of education and propaganda with a cultural approach. One of them, he composed songs such as Song of Rumekso in Wengi and Lir Ilir. The song Ilir-ilir was created by Sunan Kalijaga estimated at the end of the 15th century AD. This assumption is based on the birth of Sunan Kalijaga in 1455 AD and has an age of up to 100 years, so it is estimated at the age of 30-40 years, he created this song. Here are the lyrics to the song Ilir-ilir in two languages:

13 Jhony Hady Saputra, Mengungkap Perjalanan Sunan Kalijaga (Pustaka Media, 2010). Hal 49 


\section{Table 1. The Poetry of IIlir-ilir Song in Two Languages}

\begin{tabular}{ll}
\hline Javanese (Original) & English \\
\hline Lir-ilir, lir-ilir & 'Get up, get up!' \\
Tandure wus sumilir & 'Plants bloom' \\
Taki jo royo-royo & 'So verdant' \\
Tak sengguh temanten anyar & 'Just as the newlyweds' \\
Cah angon, cah angon & 'Son of a pastor, shepherd' \\
Penekno blimbingkuwi & 'Climb (tree) starfruit it'! \\
Lunyu-lunyu penekno & 'Let slippery to keep you climbing' \\
Kanggo mbasuh dodotiro & 'To wash clothes' \\
Dodotiro, dodoiro & 'Your clothes, your clothes' \\
Kumitir bedah ing pinggir & 'Torn apart the side' \\
Dondomono, jlumatono & 'Stitch together, Examine!' \\
Kanggo sebo mengko sore & 'To appear before you this afternoon' \\
Mumpung padhang rembulane & 'As long as the moon was shining brightly' \\
Mumpung jembar kalangane & 'As long as a lot of free time' \\
Yo sorako, sorak iyo!! & 'Battle cry with cheers Yeah!' \\
\hline
\end{tabular}

(Source: Andi, 2013, http://musikdanlyrics.blogspot.co.id/)

Based on symbolic and connotative language content, the lyrics of the song Ilir-ilir consist of 53 words, 5 words that duplicate as follows: Lir-ilir, royo-royo, cah-angah-cah, lunyulunyu, dodot iro-dodot iro, and only has 9 symbolic meanings consisting of 6 natural symbols (if the symbol uses natural reality), namely: lir-ilir, tandure, ijo royo-royo, blimbing, rembulane, and sore, evening, and 3 blank symbols (if the symbol refers to its meaning connotative, the reader does not need to interpret it because the reference meaning is general), namely: temanten anyar, cah angon, dodot iro. There are 31 connotation meanings (connotative meaning is a denotation 
meaning that has been added. A word is said to have a connotative meaning if the word has a "taste value", both positive and negative) namely: lir-ilir, lir-ilir, ijo royo-royo, temanten anyar, cah angon, cah angon, blimbing, lunyu-lunyu penekna, dodot ira, dodot ira-dodot ira, bedah, dondomono, jlumatono, sebo, padang rembulane, jembar kalangane, surako, surak.

Accompanied by the 5 duplicated words, according to Ramlan (1985,) that the repetition of grammatical units, both in whole or in part, both with phoneme variations or not. The result of repetition is called a repeated word, while the unit that is repeated is the basic form. According to Muslich $(2010$, 48) explains the process of repetition is a word-formation event by not repeating the basic form, either in whole or in part, both varying phonemes or not, whether combined with affective or not. While according to Chaer $(2007,182)$, reduplication is a morphemic process that repeats the basic form, both as a whole, partially (partially) or with sound changes, namely: lir-ilir, lirilir, royo-royo, cah angon-cah angon, lunyu-lunyu, dodot iradodot ira (Suryana, 2013).

\section{The Value of Education and Da'wah Based on Culture}

The following is explained the value of cultural-based education and propaganda values in the song Ilir-ilir by taking the meaning of the sentence by sentence as follows:

The description “Ilir-ilir tandure wis sumilir". The word Ilirilir comes from the Javanese word "slipping" which means Indonesian is awake from sleep. The point is, people who have not converted to Islam are said to be still sleeping / unconscious. In this song, the word "Ilir-ilir, Lir-ilir" is repeated twice, meaning "wake-up", waking up to a new realm of thought, which is to convert to Islam. 
Whereas in the second row "Tandure wis sumilir," consists of: "tandure" means "seed" that is ready to be planted. "Wis Sumilir" means it has grown. So in the line "tandure wis sumilir" the same as the seeds planted have started to grow. The seed here means faith, namely faith in Islam. All people born on this earth have been awarded the seed of faith by Allah. Knowingly or not depends on the people concerned. If the person concerned is "aware" of the seeds of faith in him and wants to maintain them well every day, then the seeds of faith will flourish, of course, will also produce good fruit. Treatment of the seeds of faith can be in the form of prayer discipline, dhikr, reading the Koran, attending majelis taklim, listening to religious lectures through various media, establishing good relations (silaturrahim) with religious leaders and fellow Muslims, and many more fertilizers in the form of soul food and other souls, which of course are carried out with full sincerity.

The description "Tak ijo royo-royo, Tak sengguh pengantin anyar". "Tak ijo royo-royo" means growing fast, fresh green leaves. The meaning of the phrase seems to emphasize the pleasing "appearance" of the Muslim person. There is a seed of faith that is always cared for that makes a Muslim person physically and mentally healthy. The phrase "Ijo royo-royo" is a symbol of fertile plants because it is well cared for. "Tak sengguh penganten anyar" the new bride. The bride is the bride and groom. This analogy is attributed to humans for their faith beliefs, which have only recently met as brides. A newlywed couple is a person who is a very happy life. Likewise with people who plant the seeds of faith and flourish by carrying out Islamic law, then he becomes a happy person as happy people who are becoming new brides. Solid faith which is described by the phrase "tak ijo royo-royo" must always be maintained, watered, and cared for properly. Plants can no longer "tak ijo royo-royo" when exposed 
to pests. This analogy can be related to a Muslim's faith. Preservation of faith to remain strong must be able to dispel pests, for example, gambling, stealing, adultery, drinking, and the like is an act of negation that needs to be eradicated from the Muslim person.

The phrase "Cah Angon - Cah Angon, Penekno BlimbingKuwi". "Cah angon" means shepherd's child. The words are repeated even twice, which means that here there is the emphasis, there is an important command. The command is: "penekno blimbingkuwi" (climb the star fruit). This order is given to subordinates / lower positions than superiors / higher positions. This analogy is a memorable one "parents who rule their children. "Why should be governed is "cah angon?" There is a shepherd, there must be someone shepherding. The meaning of cah angon (not just a shepherd's child) is human. Humans who as shepherds pastor their passions. Lusts that each person has, if not shepherded, can be destructive and of course many violate religious orders/rules. The human person must be able to act as a good shepherd. In essence, "cah angon" is a designation intended for a Muslim who becomes a shepherd of his passions.

"Penekno BlimbingKuwi." This sentence does not mean you have to climb the star fruit, but "climb the star fruit tree." The command to climb is the blimbingtree to memetic its fruit. The question arises, why should star fruit be the personification here, why not durian fruit, or Jackfruit? We know that the star fruit has 5 sides. Now, this picture refers to the five pillars of Islam, namely the two sentences of the Creed, establishing prayer, paying zakat, fasting Ramadan, and performing the pilgrimage.

The description "Lunyu - Lunyu yo Penekno kanggo Mbasuh Dodotiro". The Indonesian language of "Lunyu-lunyu yo penekno" is "Even though it is slippery, keep climbing" (this line is related to the previous line " Cah angon-cah angon, peneken 
blimbingkuwi"). Slippery is an obstacle for the climber. Must climb in earnest and be careful. If not, it will slip down. It's the same with religious orders. If it is not carried out seriously, it is not impossible to slip into the hole of sin that takes a person to hell. In plain analogy, the way down is easier than the way up, the road to hell is easier than the road to heaven. Isn't drinking, gambling, adultery, lying, slandering easier than preventing munkar, doing prayers, and fasting? However, for "cah angon" who obey, the command of Allah. to climb "Blimbing" was not a burden and not something heavy for him (to reach a delicious fruit, namely heaven).

"Kanggo mbasuh dodotiro" has a purpose: useful to cleanse or purify our beliefs, until they truly become sacred beliefs. Dodot is oversized clothing in the palace environment. Dodot $=$ clothes. This analogy is likened to "trust." During the "Wali Songo" era, many people embraced Hinduism, Buddhism, and Animism. Things like that are washed with "Islamic faith" by Wali Songo, so that a clean and true religion is Islam. One of the cleaners is the Five Pillars of Islam.

Description "Dodotiro - Dodotiro Kumitir Bedah ing Pinggir, Dondomana Jlumatana, Kanggo Seba Mengko Sore". The previous information explained that "dodot" to describe the religion or belief held. " Kumitir bedah ing pinggir" means: many tears in the edges. Next, there is the command "dondomana jlumatana" - sewn/repaired. Damaged clothes should be repaired so that they are suitable for use again. Likewise with our beliefs. If it is damaged (because of the sins that have been committed), it should be corrected by asking forgiveness from Allah (repent) and doing the pillars of Islam as well as possible. "Kanggo seba" means: "come, face the Almighty, that is Allah." Whereas "sore" or afternoon means "the end of the journey." End of human life journey. So, the purpose of "Kanggo sebo mengko sore" is: "to 
face God later when the journey of life is over." The lesson is how we carry out the commands in practicing the pillars of Islam well as provisions to face God later when life is over.

Description "Mumpung Padang Rembulane, Mumpung Jembar Kalangane". The English translation is: "while the moonlight is bright, while space is wide," clear moonlight at night. Without the moonlight at night (without any lighting) it will be pitch dark, unable to see anything. That is when "dark" people will be difficult (even unable) to distinguish between rights and vanity (which is good/right and what is bad/wrong / haram). However, in that dark atmosphere, there is a "lighting" from the light of the moon (Islamic light), so that it can be seen which are good and which are bad, which are right and which are vanity. "Mumpung jembar kalangane" - Wide moonlight coverage, able to illuminate large areas. So, the purpose of "Mumpung padang rembulane, Mumpung Jembar Kalangane" is while there is still a chance to repent to reach heaven (to seek blimbing) / to carry out religious orders, namely the five pillars of Islam earlier. This is because, with the Islamic light, we can distinguish between what is right and what is wrong. Good opportunities and broad should not be wasted away. All of that is an invitation for all mankind to carry out the five pillars of Islam properly and correctly.

The phrase "Yo Surako, Surak Hiyo". The line above (let's cheer, cheer) is an invitation to cheer. Charlie is an expression of pleasure and happiness for those concerned. Why be happy? Nothing else is because he has succeeded in carrying out the command "Peneken blimbingkuwi, lunyu-lunyu ya peneken." Happy or happy was obtained as a gift from his work "climbing the star fruit" (heaven). The core of the line is, inviting "Si Cah Angon" (a Muslim) who has carried out the command " peneken blimbing kuwi" well, to be happy because he will get the reward in the form of heaven (perfected from Maulana, 2011). 
From the description above we see how Sunan Kalijaga translates Islamic teachings smartly in a series of poems and short songs that have profound meanings about the need for someone to pay attention to our lives while in this world. The content of the song Ilir-ilir advises the public not to be oriented only on the mundane but also oriented to life in the eternal realm, the afterlife. So that the life of the world and the hereafter must be balanced. Sunan Kalijaga reminds people that we have personal accountability to God because all our actions will be held accountable. Sunan Kalijaga offers Islam as a way and provision to face death and ultimate accountability. Armed with understanding the teachings of Islam in depth Pillars of Faith namely Sahadat, Prayer, Zakat, Fasting, Hajj and always doing good things away from bad deeds to get a peaceful life in the world and eternally happy in the hereafter. 14

The song Lir Ilir has a deep meaning about the values of education and $d a^{\prime} w a h$ with a heart or taste approach. If we can interpret it in depth, this song will inspire the spectacles of our lives. This song by Sunan Kalijaga gives the essence of life in the form of beautiful poetry. This is as the word of Allah:

"O you who believe, fulfill the call of Allah and the Apostle's call when the Apostle calls you to a person who gives life to you (Surah Al-Anfal [8], 25)".

The legendary work of the song IIlir-ilir by Sunan Kalijaga is an educational media and Islamic preaching that is very popular in his day until now in the millennial era. Sunan Kalijaga is a member of Wali Songo (nine Waliullah) who is known as a wise and intelligent person. He is the only member of Wali Songo who is of Javanese origin. Therefore, in his mission to spread Islam, he used an approach of Javanese tradition that was easily

14 Saputra. Hal 58-67 
understood among Javanese people who generally still had strong Hindu and Buddhist cultures. The influence of education and preaching Sunan Kalijaga was not only known among ordinary people but also known in the Javanese aristocracy at that time. Therefore, he is also known by Muslim communities who are still fanatical about the Javanese tradition called "Islam Abangan". The meaning of "Abangan" in this context is Javanese people who have converted to Islam but they still carry out local Javanese traditions that have a strong influence from Hinduism and Buddhism. Therein lies the importance of education and cultural propaganda as practiced by Sunan Kalijaga, because this method is not commonly carried out as Islamic propaganda in the Arab States, particularly in terms of its cultural approach.

Sunan Kalijaga's policy in implementing a cultural approach was his personal decision not Walisongo's decision as to the official Walisongo Organization (Majelis Walisongo) at that time. Sunan Kalijaga argued that the Javanese nation was indeed pure Javanese with Javanese culture, it did not need to be replaced with Arabic culture. Only in matters of belief must be replaced with Islamic beliefs, with a deep understanding. So at that time, Javanese arts and culture were not erased by Sunan Kalijaga, but given the color of Islam, ritual ceremonies such as the salvation of his prayer were replaced with Islamic prayers. Shadow puppets have been changed in such a way that they do not violate Islamic law. Up to his journey, Sunan Kalijaga produced monumental works of Javanese culture by making songs such as IlirIlir and Dandang Gula, which included cultural-based educational and religious requirements. 15

15 Nurrahmah Juraiva Wandri, "ANALISIS LAGU LIR ILIR KARYA SUNAN KALIJAGA ARANSEMEN LANGEN PARAN DUMADI" (Universitas Pendidikan Indonesia, 2015). Hal 45-50 


\section{The popularity of Lir Ilir Songs}

The Ilir-ilir song in the days of the Javanese Kingdom of Islam was very popular as a game song (Javanese: dholanan) among children and people in Java. During the Old (Orde Lama) and New Order periods (Orde Baru), this song was registered as a compulsory song in public institutions in East and Central Java. But in the current reform era, the song children rarely sing the song even rarely again. This song is popular again echoed both in religious nuances as performed by the music group Kiai Kanjeng which was pioneered by artist and humanist Emha Ainun Najib and in the original concept of dholanan which began to be popularized by a band called Rich Band. This religious song became increasingly popular overseas after Habib Sheikh Assegaf played the Lir-Ilir song excitedly at the 2013 Mega Maulid Majlis in Kuala Lumpur.

Carrol Mclaughlin, a harp professor from Arizona University, was fascinated by this song and often played it. Maya Hasan, Indonesian Harp player once said that he wanted to understand the philosophy of this song. They, together with Hiroko Saito from Japan, Kellie Marie Cousineau from the United States, and Lizard Rodrigues from Puerto Rico had tried to translate them into Jazz at a music concert. Thus the Ilir-ilir song has been very popular throughout the ages not only sung by Islamic religious and religious qosidah singers but is also loved by world-class musicians.

\section{Discussion}

Both historically and its implementation throughout Islamic history, Islamic education and preaching activities are like two sides of a coin in one coin that cannot be separated from one another. In every missionary activity, there is an Islamic educational activity. Conversely, in every Islamic educational 
activity, it also contains elements of $d a$ 'wah. Therefore, in this study, the author examines the values of the song Ilir-ilir Sunan Kalijaga which supports the educational strategy and Islamic $d a$ 'wah at the same time. This is the novelty or important findings of this study.

Related to the discussion of education, Langeveld in Munib states that education is guidance given by adults to children who are not yet mature to achieve the goal, namely maturity. In line with the notion of education, education is formed giving guidance from one person to another that makes a person from not knowing to understand. The guidance can be in the form of guidance that is building one's maturity which includes aspects of attitude, knowledge, and skills. And it would be more precise that the education and guidance activities are based on tradition or culture in which students all the time unite in everyday life.

Rusydi explained that Indonesia as a country with considerable potential in the development of education must of course be able to adjust to current conditions. The inevitability of more educational formats has become our shared obligation in the effort to realize them. Making an effort to liberate education which has been coloured by values that hegemony the creativity of students' thinking, has required us to try to change while trying to give a new concept of actual education. Provide full opportunities for students to develop abilities following their talents. This will have positive implications for their natural growth and development.16

While referring to the cultural-based propaganda strategy, we can refer to some narrations of the hadith, both authentic (shahih) and hasan explained that Islam allowed some of the customs of Arab societies before Islam that did not contradict Islamic law and laws or were in harmony with the teachings of Islam itself.

16 Rusydi, “Pendidikan Berbasis Budaya Cirebon.” Hal. 67 
Therefore, the Messenger of Allah. does not erase all the customs and culture of the Arab community that existed before the arrival of Islam, such as tawaf, sacrifice, thanksgiving, including haqiqah by slaughtering goats, marriage customs, and so on. But on the contrary, the Prophet Muhammad Saw. forbid cultures that contain elements of shirk, such as worship of gods, ancestors, and ancestors, violating human rights and cultures that conflict with Islamic customs.

So, as long as customs and culture do not conflict with Islamic teachings, the community in this case the educators and preachers of Islam are still welcome to use approaches, strategies, as well as cultural-based education and propaganda media. However, if these traditions and cultures contradict Islamic teachings, such as exhibiting genitals on some of the traditional customs of the area, or the culture contains shirk or has origins in shirk rituals and worship or worship of gods or gods other than God, then cultures such as it should be abandoned because it contains haram law on Islamic teachings.

For this reason, according to Muchtar, da'wah must be presented in a way that is smarter, wiser, and able to make mad'î easily accept, not avoid it.17 So preaching must see the situation and conditions mad' $\hat{u}$. The verse explains that God sent the Apostles to preach according to the language of their people, meaning that the preaching was adapted to the state of mad' $\hat{u}$. The awareness of this verse has made it possible for Islamic preachers in Indonesia to choose the cultural approach as a missionary approach. Islam in its adaptation to Indonesian society, which is geographically distant from the beginning of the

17 Adeng Muchtar Ghazali and Maman Abd Djaliel, Pemikiran Islam Kontemporer: Suatu Refleksi Keagamaan Yang Dialogis (Pustaka Setia, 2005). Hal. 46 
emergence of other religions, is more likely to spread religious attitudes towards the local culture. For carriers of cultural preaching, the phrase "Lisaani Qaumihi" is interpreted as the local culture of local people or customs including Language. 18

Historically, according to Muchlas, it also had the same meaning as the first three Islamic attitudes when it came to Arab life rich in the local culture. The three attitudes are accepting and acknowledging, changing and adjusting, and rejecting. 19 Wahyudi who researcher in education base culture explains that culture in its various embodiments can serve as a medium of education and learning in teaching and learning activities for learners. In cultural-based learning, the role of culture in providing an exciting new environment for learning an area of knowledge is integrated with active interactions in the learning process. Culture is a method for students to transform the results of their observations into creative forms and principles in the fields of science. Culture in its many embodiments, can be instrumental as a medium of education and learning in the process of learning.20

From the above description, we can conclude that the song Ilir-ilir monumental work of Sunan Kalijaga as studied in this study contains strategies as well as educational values and Islamic preaching at the same time. So that we can implement the work of Sunan Kalijaga, we develop, modify and even create new

18 Ilyas Ismail and Prio Hotman, Filsafat Dakwah Rekayasa Membangun Agama Dan Peradaban Islam (Kencana, 2013). Hal. 247

19 Imam Muchlas, Deni al-Asy'ari, and Hasanudin, Landasan Dakwah Kultural (Membaca Respon Al-Qur'an Terhadap Adat Kebiasaan Arab Jahiliyah) (Suara Muhammadiyah, 2006). Hal. 199-222

20 Muhammad Dani Wahyudi, "PEMBELAJARAN INOVATIF BERBASIS BUDAYA LOKAL UNTUK MEWUJUDKAN SEKOLAH UNGGUL DI PENDIDIKAN PRA SEKOLAH," Prosiding SEMNAS PS2DMP ULM 2, no. 2 (2016): 12-17. 
media to support the development of strategies, values, and media education and cultural-based Islamic preaching to avoid the harsh teachings of Islam.

\section{Conclusion}

The results of this study concluded the following: First, Sunan Kalijaga created the song Ilir-ilir estimated at the end of the 15 th century AD. Second, the song Ilir-ilir has symbolic and connotative language content, consisting of 53 words, 5 words that duplicate (repetition), 9 meanings natural symbols (natural reality), 3 blank symbols, and 31 connotation meanings (have sense meanings). Third, the education and $d a$ 'wah strategies contained in the Ilir-ilir Song, namely: 1) With a cultural approach. Sunan Kalijaga invites and educates the public to embrace Islam as a new religion that came to Java around the 1315 century AD. 2) Persuasively, Sunan Kalijaga made people aware of Islam by carrying out the five pillars of Islam while leaving all beliefs and deeds prohibited by Islam. 3) With the metaphor of Blimbing fruit, Sunan Kalijaga assures people that whoever obeys the commands of Islam, will find peace and happiness in living in this world and the hereafter. Fourth, Islamic educators and preachers in various forms, have created the song Ilir-ilir as a strategy as well as cultural-based education and propaganda media that remain popular in the millennial era.

\section{Bibliography}

Amin, Samsul Munir, and Baihaqi Nu'man. Rekonstruksi Pemikiran Dakwah Islam. Amzah, 2008.

Anwar, Syamsul. "Pandangan Islam Terhadap Kesenian." Yogyakarta: Majelis Kebudayaan Muhammadiyah. Universitas Ahmad Dahlan, 1995.

Ghazali, Adeng Muchtar, and Maman Abd Djaliel. Pemikiran 
Islam Kontemporer: Suatu Refleksi Keagamaan Yang Dialogis. Pustaka Setia, 2005.

Ismail, Ilyas, and Prio Hotman. Filsafat Dakwah Rekayasa Membangun Agama Dan Peradaban Islam. Kencana, 2013. Joseph, Bleicher. "Contemporary Hermeneutics." London: Routledge and Kegan Paul, 1980.

Kasdi, Abdurrohman. "The Role of Walisongo in Developing the Islam Nusantara Civilization.” Addin 11, no. 1 (2017): 1-26. Margono, S. "Metode Penelitian Pendidikan, PT." Rineka Cipta, Jakarta, 2000.

Moelong, J. "Lexy. 2012." Metode Penelitian Kualitatif. Bandung: PT Remaja Rosdakarya, n.d.

Muchlas, Imam, Deni al-Asy'ari, and Hasanudin. Landasan Dakwah Kultural (Membaca Respon Al-Qur'an Terhadap Adat Kebiasaan Arab Jahiliyah). Suara Muhammadiyah, 2006.

Muhadjir, Noeng. "Metode Penelitian Kualitatif Edisi IV." Yogyakarta: Rake Sarasin, 2000.

Nuh, Sayyid Muhammad. Stategi Dakwah Dan Pendidikan Umat. Yogyakarta: Himam Prisma Media, 2004.

Rusydi, Ibnu. "Pendidikan Berbasis Budaya Cirebon." Intizar 20, no. 2 (2014)

Saputra, Jhony Hady. Mengungkap Perjalanan Sunan Kalijaga. Pustaka Media, 2010.

Sulthon, Muhammad, H M Amin Syukur, and M Adib Abdushomad. Menjawab Tantangan Zaman: Desain Ilmu Dakwah: Kajian Ontologis, Epistemologis Dan Aksiologis. Pustaka Pelajar diterbitkan atas kerjasama dengan Walisongo Press, 2003.

Wahyudi, Muhammad Dani. "PEMBELAJARAN INOVATIF BERBASIS BUDAYA LOKAL UNTUK MEWUJUDKAN SEKOLAH UNGGUL DI PENDIDIKAN PRA 
198 | Mulyono

SEKOLAH." Prosiding SEMNAS PS2DMP ULM 2, no. 2 (2016).

Wandri, Nurrahmah Juraiva. "ANALISIS LAGU LIR ILIR KARYA SUNAN KALIJAGA ARANSEMEN LANGEN PARAN DUMADI." Universitas Pendidikan Indonesia, 2015. 